\title{
The Inhibition Effect of Cinnamon Extract on Leaching of Aluminum Cook Wares in NaCl Solutions at Quasi-Cooking Condition
}

\author{
Layla A. Al Juhaiman*, Raesah A. Al-Shihry, Hassan M. Al Hazmei \\ Chemistry Department, King Saud University, Riyadh, KSA \\ Email: ${ }^{\text {ljuhiman@ksu.edu.sa }}$
}

Received 1 July 2015; accepted 20 September 2015; published 23 September 2015

Copyright (C) 2015 by authors and Scientific Research Publishing Inc.

This work is licensed under the Creative Commons Attribution International License (CC BY). http://creativecommons.org/licenses/by/4.0/

cc) (i) Open Access

\section{Abstract}

The contribution of cinnamon extract on leaching of aluminum (Al) cook wares was investigated using two aluminum alloys (Indian and Egyptian) and pure Al. The cinnamon (Cin) was extracted by heating the Cin sticks at $90^{\circ} \mathrm{C}$ in distilled water for an hour to make the $10 \%$ stock solution. This study was done in aqueous solutions in presence and absence of $1 \% \mathrm{NaCl}$ using weight loss at $90^{\circ} \mathrm{C}$. Moreover surface study (SEM and EDX) and electrochemical methods (Open Circuit Potential and Tafel plot) were applied. The addition of Cin solutions to $1 \% \mathrm{NaCl}$ decreased the corrosion rates in weight loss and electrochemical method compared to $1 \% \mathrm{NaCl}$ solutions which showed an inhibitive property of Cin solution. The inhibition was found to obey the modified Langmuir isotherm with a negative Langmuir $\Delta G_{\text {ads }}$ indicating the spontaneous nature of adsorption even at $90^{\circ} \mathrm{C}$. The EDX surface analysis of the $\mathrm{Al}$ surface immersed in $\mathrm{Cin}+\mathrm{NaCl}$ revealed the composition of the pits formed. From Tafel method, it was found that the corrosion current density of pure Al was more than that of the Egyptian alloy. The apparent activation energy values for $\mathrm{Cin}, \mathrm{Cin}+\mathrm{NaCl}$ and $\mathrm{NaCl}$ solution were evaluated and discussed.

\section{Keywords}

Cinnamon Extract, Aluminum Alloys, Weight Loss Method, Inhibition, Surface Study, Open Circuit Potential, Tafel Plot

\section{Introduction}

Aluminum (Al) was regarded a neurotoxin agent because it was associated with some diseases like dialysis encephalopathy and bone disorder due to its accumulation in brain, bones, and liver [1]. Sources of $\mathrm{Al}$ entering the

*Corresponding author.

How to cite this paper: Al Juhaiman, L.A., Al-Shihry, R.A. and Al Hazmei, H.M. (2015) The Inhibition Effect of Cinnamon Extract on Leaching of Aluminum Cook Wares in $\mathrm{NaCl}$ Solutions at Quasi-Cooking Condition. Journal of Surface Engineered Materials and Advanced Technology, 5, 177-189. http://dx.doi.org/10.4236/isemat.2015.54020 
human body include water, beverages, food, medicines, food additives and leaching from $\mathrm{Al}$ cook wares. In 2007, the Joint Committee on Food Additives established a new Provisional Tolerable Weekly Intake (PTWI) for Al of $1 \mathrm{mg} / \mathrm{kg}$ body weight for an adult instead of the old 1989 PTWI of $7 \mathrm{mg} / \mathrm{kg}$; this PTWI value applies to all aluminum entering the human body including food, beverages and drugs [2]. There was a continuing interest of $\mathrm{Al}$ leaching from $\mathrm{Al}$ cock wares and food and its possible relation to $\mathrm{Al}$ toxicity especially to the elderly and to people with kidney failure. Many studies shed some light on $\mathrm{Al}$ leaching in aqueous solutions containing food and it was established that cooking acidic food in Al utensils causes high Al leaching into food [3]-[8].

Cinnamon is one of the most popular spices used by mankind. The genus Cinnamomum (family: Lauraceae) consists of 250 species of trees and shrubs distributed in Southeast Asia, China and Australia [9]. The dried inner bark of cinnamon contains cinammaldehyde, volatile oil, fixed oil, tannin, resin, proteins, cellulose, pentosans, starch, calcium oxalate and mineral elements. The relative abundance of these constituents varies according to location, age of the tree, climatic condition, harvest time and duration of storage [9].

It is well known that $\mathrm{Al}$ dissolution is highly dependent on $\mathrm{pH}$, temperature, and the presence of complexing agents. There is a continuous use of $\mathrm{Al}$ cook wares in different countries despite its association with serious health problems. Corrosion control of metals is an important activity of technical, economical, and environmental importance. The use of inhibitors is one of the best options of protecting metals and alloys against corrosion. Some inhibitors retard corrosion by adsorption to form a thin invisible film while others form visible precipitates which coat the metal and protect it from aggressive attack. Other inhibitors, when added to an environment, retard corrosion but do not interact directly with metal surface [9].

The toxicity of inorganic corrosion inhibitors to the environment has prompted the search for green corrosion inhibitors for metals as they are biodegradable and do not contain heavy metals or other toxic compounds. Naturally occurring organic substances and plant extract are widely used as corrosion inhibitors [10]-[19]. Moreover, the electrochemical behavior and corrosion of aluminum alloys in chloride media were widely studied [20]-[22].

The purpose of this paper is to study the leaching behavior of two $\mathrm{Al}$ alloys used for $\mathrm{Al}$ cook wares (Egyptian and Indian alloys) in aqueous solutions containing cinnamon extract in presence and absence of $1 \% \mathrm{NaCl}$ at concentrations $1-5 \mathrm{w} / \mathrm{w}$ at $90^{\circ} \mathrm{C}$ to imitate real cooking conditions. Weight loss method, surface study and electrochemical methods (Open Circuit Potential and Tafel plots) were applied. For the electrochemical methods pure Aluminum (Al) was used for comparison in addition to the Egyptian and Indian alloys.

\section{Materials and Methods}

\subsection{Materials}

The cinnamon sticks used in this study were bought from the local market. Pure Al (99.99\%) from Good fellow was used in addition to two kinds of $\mathrm{Al}$ cook wares chosen from the local market from Egypt (Eg alloy) and from India (In alloy). $\mathrm{NaCl}$ (AR) was purchased from $\mathrm{BDH}$.

\subsection{Methods}

\subsubsection{Extraction Method}

The best method which was adopted was heating cinnamon sticks at $90^{\circ} \mathrm{C}$ in distilled water for an hour to make $10 \% \mathrm{w} / \mathrm{v}$ solution. This method is suitable because it resembles real cooking condition. The cinnamon extract stock solution was used to prepare the following concentrations $(1 \%, 2 \%, 3 \%, 4 \%, 5 \%)$. These concentrations are close to those used in real cooking.

\subsubsection{Weight Loss Method}

To study $\mathrm{Al}$ leaching of $\mathrm{Al}$ alloys weight loss method (WL) was employed in cinnamon solutions w/without $\mathrm{NaCl}$. The mean of two to three replicate experiments was reported. The two Al cook wares were cut into rectangular specimens of dimensions $2 \times 2.2 \mathrm{~cm}$ and $2 \mathrm{~mm}$ thickness. The average exposed area was $9.0 \pm 0.10 \mathrm{~cm}^{2}$. The following procedure was done prior to each experiment: wet polishing with emery paper (400 - 1200) grade, washing with distilled water, then ultrasonic cleaning in acetone for 2 minutes, then air drying. The Al samples were weighed in a sensitive balance then immediately immersed in the hot cinnamon solution for 1 hour.

Ultrasonic cleaner from Cole Palmer was used to clean the Al specimens before corrosion experiments. A 
sensitive balance ( $\pm 0.0001 \mathrm{~g}$ from Metler Toledo) was used to weigh the Al specimens before and after corrosion experiments. After the leaching experiments the $\mathrm{Al}$ samples were immersed in a cleaning solution of $2 \%$ $\mathrm{CrO}_{3}+5 \% \mathrm{H}_{3} \mathrm{PO}_{4}$ at $80^{\circ} \mathrm{C}$ for 10 minutes to remove the reaction products. Finally it was washed with distilled water (DW) and acetone then it was weighed again to determine the weight loss. All experiments were performed in aerated solutions and maintained at $90^{\circ} \mathrm{C} \pm 1^{\circ} \mathrm{C}$.

\subsubsection{Surface Study Method}

After the leaching experiments some of the Al samples were kept for surface study. The surface morphology of Al samples was studied using a Scanning Electron Microscope (SEM) from (Joel-JSM-6380). Moreover the Al surface after weight loss was analyzed by Energy Diffraction X-Ray (EDX).

\subsubsection{Electrochemical Methods}

For the electrochemical studies, two cells were used to estimate the small changes of Al leaching using a galvanostat/potentiostat (from ACM). The first one was a three electrode cell and the working electrode was Pure Al (99.99\%) with an exposed surface area of $0.20 \mathrm{~cm}^{2}$. The second cell was a sample holder from Radiometer and the working electrode was cut into circular disks from Al cook wares with $1.4 \mathrm{~cm}$ diameter and an exposed area of $1.13 \mathrm{~cm}^{2}$. The reference electrode for both cells was saturated Calomel electrode (SCE) and the auxiliary electrode was Platinum. All electrochemical experiments were performed in aerated solutions and maintained at $60^{\circ} \mathrm{C} \pm 1^{\circ} \mathrm{C}$ using a circulating water bath (from Haak). After running open circuit potential for 1 hour, Tafel measurements were done to obtain the corrosion current density by scanning the potential, $E_{s s} \pm 250 \mathrm{mV}$ at a rate of $1 \mathrm{mV} / \mathrm{s}$.

\section{Results}

\subsection{Weight Loss Method}

Corrosion rate law $(C R)$ was used to calculate $\mathrm{Al}$ leaching using the following equation:

$$
C R=\frac{\Delta W}{A \times t}
$$

where $\Delta w$ is the weight loss of $\mathrm{Al}$ sample calculated from subtracting the original sample weight minus the sample weight after the immersion experiments (mg); $A$ is the exposed surface area of Al sample $\left(\mathrm{cm}^{2}\right)$ and $t$ is the immersion time (hour). The alloying elements of the two $\mathrm{Al}$ alloys used for $\mathrm{Al}$ cook wares (Egyptian and Indian alloys) was determined as shown in Table 1.

The percentage inhibition efficiency (IE\%) and surface coverage $(\theta)$ is calculated from applying the following equations:

$$
\begin{gathered}
I E \%=\mathrm{I}\left(1-\frac{C R}{C R_{\circ}}\right) \mathrm{I} \times 100 \\
\theta=\frac{I E \%}{100}
\end{gathered}
$$

where $C R$ 。 and $C R$ are the corrosion rate in the presence and absence of pure Cin.

The weight loss measurements were performed at $90^{\circ} \mathrm{C}$ to imitate real cooking conditions. The study was performed in tab water ( $\mathrm{Tab} \mathrm{W}$ ) and distilled water (DW). The $\mathrm{pH}$ of the solutions in the present study was in the range of 5.4 - 5.5 without $\mathrm{NaCl}$ and about 6.3 - 6.5 in presence of $\mathrm{NaCl}$. There was no significant change in $\mathrm{pH}$ after the leaching experiments. The study was done in cinnamon solutions w/without $\mathrm{NaCl}$ prepared from $10 \%$ w/v stock solution: 1\%, 2\%, 3\%, 4\%, 5\% w/v as shown in Table 2 for the Eg alloy and the In alloy. From gravimetric measurement (Table 2), the following observations are noticed:

- The extent of Al leaching in Cin solutions is much less than Al leaching due to distilled water only which reflects the inhibitive effect of Cin solutions.

- For both alloys, the addition of $\mathrm{Cin}$ to $\mathrm{NaCl}$ in $\mathrm{DW}$ and tab $\mathrm{W}$ decreased the Al leaching in all concentrations compared to $\mathrm{NaCl}$ only. The percentage of surface coverage of the In alloy is smaller than the Eg alloy. The 
Table 1. Percentage of alumium alloying elements (In. $\mathrm{Al}=95.95, \mathrm{Eg} . \mathrm{Al}=96.55)$.

\begin{tabular}{ccccccccccc}
\hline$\%$ & $\mathrm{Ti}$ & $\mathrm{Sn}$ & $\mathrm{Co}$ & $\mathrm{Cu}$ & $\mathrm{Cr}$ & $\mathrm{Ni}$ & $\mathrm{Mo}$ & $\mathrm{Fe}$ & $\mathrm{Mg}$ & $\mathrm{Si}$ \\
\hline In. & 0.19 & 0.99 & 0.36 & 0.21 & 0.19 & 0.14 & 0.09 & 0.65 & 0.67 & 0.56 \\
Eg. & 0.92 & 0.59 & 0.10 & 0.12 & - & 0.20 & 0.06 & 0.50 & 0.46 & 0.60 \\
\hline
\end{tabular}

Table 2. Effect of concentration of Cin solutions on leaching of $\mathrm{Eg}$ and In alloys from WL method at $90^{\circ} \mathrm{C}$.

\begin{tabular}{|c|c|c|c|c|c|c|c|}
\hline \multirow{2}{*}{ Solution } & \multirow{2}{*}{$\begin{array}{l}\% C \\
(w / v)\end{array}$} & \multicolumn{3}{|c|}{ Eg alloy } & \multicolumn{3}{|c|}{ In alloy } \\
\hline & & $\begin{array}{c}\mathrm{CR} * \mathrm{E} 4 \\
\text { (g/cm² } \mathrm{cm}^{2} \text { days) }\end{array}$ & $I E \%$ & $\Theta$ & $\begin{array}{c}\mathrm{CR}^{*} \mathrm{E} 4 \\
\left(\mathrm{~g} / \mathrm{cm}^{2} \cdot \text { days }\right)\end{array}$ & $I E \%$ & $\theta$ \\
\hline Dis. W only & ---- & 3.78 & --- & --- & 3.78 & --- & --- \\
\hline Tab W only & --- & 8.92 & --- & --- & 10.50 & --- & -- \\
\hline $\mathrm{NaCl}$, Dis W & 1 & 7.04 & --- & --- & 8.35 & --- & --- \\
\hline \multirow[t]{3}{*}{ NaCl, Tab W } & 1 & 10.71 & --- & --- & 11.39 & --- & -- \\
\hline & 1 & 1.34 & --- & --- & 1.44 & --- & -- \\
\hline & 2 & 3.51 & --- & --- & 2.34 & --- & -- \\
\hline \multirow[t]{5}{*}{ Cin (DW) } & 3 & 2.95 & --- & --- & 2.79 & --- & --- \\
\hline & 4 & 2.41 & --- & --- & 2.80 & --- & --- \\
\hline & 5 & 3.17 & --- & --- & 3.62 & --- & --- \\
\hline & 1 & 3.07 & 56.4 & 0.564 & 6.94 & 16.89 & 0.17 \\
\hline & 2 & 2.76 & 60.5 & 0.605 & 7.07 & 15.33 & 0.15 \\
\hline \multirow[t]{5}{*}{$\begin{array}{c}\mathrm{Cin}+\mathrm{NaCl} \\
(\mathrm{DW})\end{array}$} & 3 & 2.62 & 62.8 & 0.628 & 6.75 & 19.16 & 0.19 \\
\hline & 4 & 2.76 & 60.8 & 0.608 & 6.36 & 23.83 & 0.24 \\
\hline & 5 & 2.75 & 61.1 & 0.61 & 6.28 & 24.79 & 0.25 \\
\hline & 1 & 5.00 & 53.3 & 0.533 & 8.55 & 24.93 & 0.25 \\
\hline & 2 & 6.99 & 34.7 & 0.347 & 9.68 & 15.01 & 0.15 \\
\hline \multirow[t]{3}{*}{$\begin{array}{l}\text { Cin + NaCl } \\
\text { (Tap W) }\end{array}$} & 3 & 7.32 & 31.7 & 0.317 & 9.46 & 16.94 & 0.17 \\
\hline & 4 & 7.80 & 27.2 & 0.272 & 9.44 & 17.12 & 0.17 \\
\hline & 5 & 5.84 & 45.5 & 0.455 & 9.50 & 16.59 & 0.17 \\
\hline
\end{tabular}

highest $I E \%$ was for $3 \% \mathrm{w} / \mathrm{v}$ where the surface coverage was 62.8 . The surface coverage of $1 \%-5 \% \mathrm{w} / \mathrm{v}$ using the Eg alloy range between 0.56 - 0.63 . On the other hand, the surface coverage of $1 \%-5 \% \mathrm{w} / \mathrm{v}$ using the In alloy range between $0.17-0.25$.

- From the gravimetric measurement, it is shown that using Tab water (which contained many ions $\mathrm{Cu}^{2+}, \mathrm{F}^{-}$, $\mathrm{Mg}^{2+}$ ) instead of distilled water, increased the CR (Al leaching). This result may be attributed to the aggressive effect of these ions and agrees with other studies [17] [18]. The protective $\mathrm{Al}_{2} \mathrm{O}_{3}$ oxide layer has amphoteric nature which dissolves in acidic and alkaline solutions. Although this protective film has low solubility in neutral medium, the aggressive effect of Chloride ions is well documented [19]-[22]. Unlike the cardamom solutions which increased the $\mathrm{Al}$ leaching in the same concentration range [19]; the Cin solutions decreased the CR compared to $1 \% \mathrm{NaCl}$ solutions. This shows the large difference between the aggressive constituents of cardamom (twelve times that of cinnamon) and the inhibitive constituents of cinnamon extract.

\subsection{Adsorption Mechanism}

Different adsorption isotherms were tested in order to find the best one which are:

1) Freundlich and Frumkin isotherms did not fit our data. 
2) Langmuir adsorption isotherm gave a good fit to our data $\left(R^{2}=0.996\right)$.

Langmuir isotherm may be formulated as:

$$
\frac{C}{\theta}=\frac{1}{K}+C
$$

where $C$ is the concentration of inhibitor (ppm), $\theta$ is the surface coverage and $K$ is the equilibrium constant of the adsorption process.

From the present study, it was found in Table 2 that the degree of surface coverage $\theta$ increased slightly with increasing concentration of $\mathrm{Cin}$ in the concentration range of $1 \%-5 \% \mathrm{w} / \mathrm{v}$. The Al leaching of Cin solutions in DW and Tab W of both alloys at $90^{\circ} \mathrm{C}$ was less than the Al leaching in DW only. A graph of $\theta$ with the change in Cin concentration showed that the curve fits the nonlinear Langmuir adsorption isotherm with a maximum around $62.8 \%$ surface coverage at $3 \% \mathrm{w} / \mathrm{v}$ as shown in Figure 1 . A good fit $\left(\mathrm{R}^{2}=0.994\right)$ was obtained for the linear Langmuir plot.

Although there was a good fit to the Langmuir graph as shown in Figure 1, it was noticed that the slope was 1.58 which is more than one as suggested by Langmuir Equation (4). Thus another isotherm should be used which is the modified Langmuir equation [23] as shown in Equation (8).

$$
\frac{C}{\theta}=\frac{n}{K_{a d s}}+n C
$$

The value of $K_{a d s}=10.97 \mathrm{~L} / \mathrm{g}$ was calculated from the reciprocal of the intercept with the value of $n=1.58$. The free-energy of adsorption $\left(\Delta G_{\circ}\right.$ ads $)$ was calculated according to the equation:

$$
\Delta G_{\text {ods }}=-R T \ln \left(55.5 K_{\text {ads }}\right)
$$

where 55.5 is the water concentration, $R$ is the universal gas constant, and $T$ is the temperature in Kelvin (363K).

$$
\Delta G_{\text {ods }}=-8.314 \times 363 \ln (55.5 \times 10.97)=-19.35 \mathrm{~kJ} .
$$

From the adsorption isotherm, the negative value of $\Delta G_{\circ}$ ads indicates that the adsorption process of the cinnamon constituent is spontaneous while adherence to the modified Langmuir adsorption isotherm indicates physisorption with mono coverage. The value being of the order less than $20 \mathrm{~kJ} / \mathrm{mol}$ indicates that cinnamon was physically adsorbed on the Al surface [10]-[16] [23]. It is assumed that the organic inhibitors establish their inhibition action via the adsorption onto the metal surface. The adsorption process is affected by the chemical structures of the inhibitors, the nature of the metal solution, $\mathrm{pH}$ and temperature [12]-[14] [23]-[25]. The chemical constituents of Cinnamon are mainly Cinammaldehyde (79.8\%) [9]. It was reported that Cinammaldehyde had an inhibitive effect on iron corrosion of chemisorptive nature [24]. Moreover the presence of Eugenol and some alcohols were reported to play an inhibitive effect as stated by Chaieb et al. [12]. We believe that the inhibitive effect of Cin solution is due to the combined effect of all of the constituents of the Cinnamon extract.
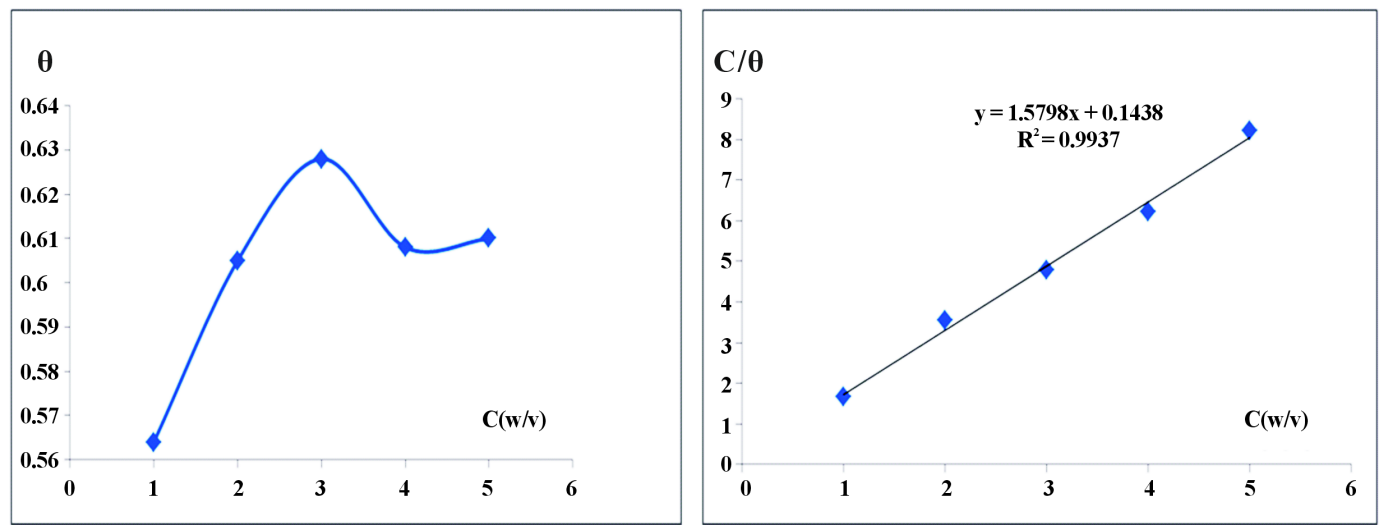

Figure 1. Langmuir isotherm for the Eg. Alloy from Weight loss in Dis water for Cin $+\mathrm{NaCl}$. Nonlinear form (left) and linear form (right). 
Physisorption involves electrostatic forces between the ionic charges at the metal/interface; this type of adsorption is stable only at relatively low temperatures. On the other hand, chemisorption involves charge sharing or charge transfer from the inhibitor molecules to the metal surface to form a coordinate type bond which is more stable at higher temperatures. Chemisorption has much stronger adsorption energy than physical adsorption [23]. The present findings and the findings of Zucchi et al. [24] about Cin in the temperature range $40^{\circ} \mathrm{C}$ $90^{\circ} \mathrm{C}$ made us postulate that the adsorption of Cin aqueous extract on $\mathrm{Al}$ surface may include both Physisorption and Chemisorption nature.

From the surface study of the, using 5\% Cin and theIn alloy, the presence of the white crystals in Figure 2 is an indication of the reaction of Cin constituents and Aluminum. The surface showed large dark are as after immersion in 5\% Cin $+\mathrm{NaCl}$ solution for one hour, as shown in Figure 3. This result is compatible with Table 2. that when using the In alloy, the CR of $5 \%$ Cin equals $3.62 \times 10^{-4} \mathrm{~g} / \mathrm{cm}^{2} \cdot$ days and the CR of $5 \% \mathrm{Cin}+\mathrm{NaCl}$ equals $6.28 \times 10^{-4} \mathrm{~g} / \mathrm{cm}^{2}$.days with $24.7 \% \mathrm{IE} \%$. The difference in CR of the two alloys in Table 2, is attributed to the difference in the alloying elements. It is noticed from the alloying elements that the Eg alloy contains $0.19 \%$ Chromium while the In alloy contains only $0.02 \%$ Chromium. Also the Eg alloy contains more Si and Ti than the In alloy. Copper, Chromium and Titanium are known to increase the corrosion resistance of metals. It is hard to attribute the corrosion resistance of the Eg alloy to these alloying elements because there are other alloying elements in the In alloy which are not present in the Eg alloy and vice versa. It is the total effect of all the alloying elements that make the difference.

\subsection{Surface Study}

The In alloy was taken as an example to investigate the effect of Cin solution because the CR is higher than the Eg alloy. After WL experiments for 5\% Cin solution, the In alloy sample was washed with distilled water only and dried. The surface showed a few white depositions after immersion in 5\% Cin solution for 1 hour, as shown in Figure 2. The addition of $\mathrm{NaCl}$ showed that these depositions turned into dark precipitate which covered the Al surface as shown in Figure 3. Analysis of the precipitate by Energy-dispersive X-ray spectroscopy (EDX) showed that this precipitate contained mainly $29.4 \%$ Carbon $+23.55 \%$ Oxygen or about $53 \%$ of the organic Cin constituents in addition to $44.46 \% \mathrm{Al}$; the rest are $\mathrm{Na}$ and $\mathrm{Cl}$ and the alloying elements.

\subsection{Electrochemical Methods}

\subsubsection{Open Circuit Potential (OCP) Method}

To detect any small changes in $\mathrm{Al}$ leaching, pure $\mathrm{Al}$ was used in addition to the two $\mathrm{Al}$ alloys. Two methods were applied: Open Circuit Potential Method followed by Tafel. All experiments were performed in aerated solutions at $60^{\circ} \mathrm{C} \pm 1^{\circ} \mathrm{C}$. As an example, the effect of change of temperature on OCP of pure $\mathrm{Al}$ for $5 \%$ Cin solutions w/without $\mathrm{NaCl}$ is shown in Figure 4 and Figure 5.

The values of $E_{s s}$ decreased with increasing temperatures with and without $\mathrm{NaCl}$. The effect of changing the temperature from $10^{\circ} \mathrm{C}-60^{\circ} \mathrm{C}$ on OCP was studied only for pure $\mathrm{Al}$ at $5 \%$ Cin solutions w/without $\mathrm{NaCl}$ as

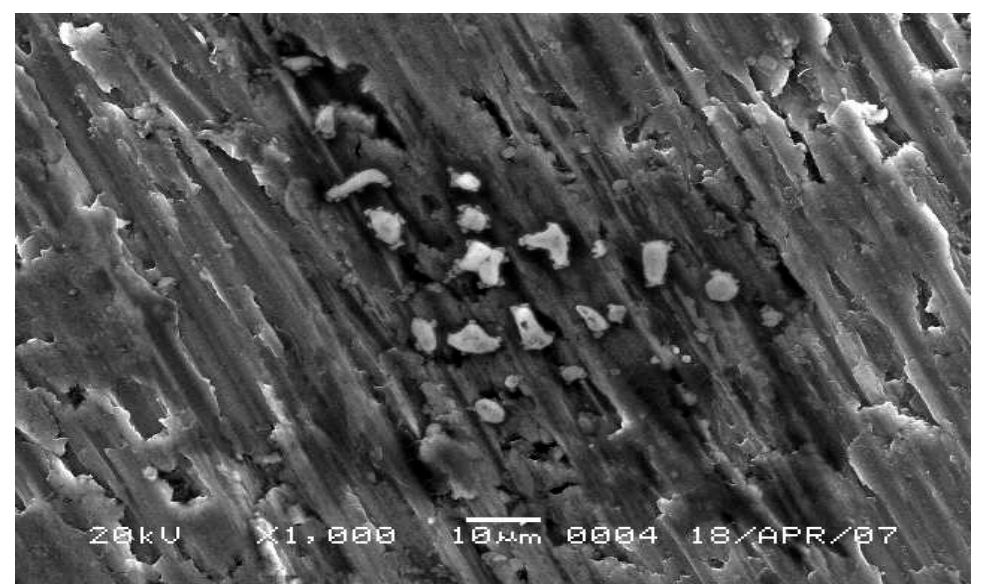

Figure 2. SEM of In alloy after immersion in 5\% Cin for 1 hour. 
x1000.1-lnd.

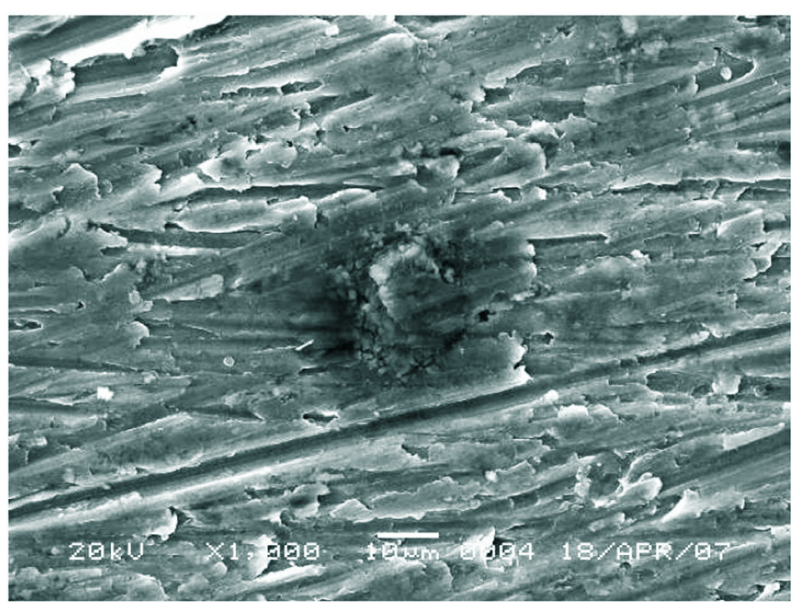

\section{JEOL}

INSTRUMENT: JSM-6380

ACCEL.VOLT(kV): 20

Org. Mag. X1000

MAGE: SEI

$<$ SEI $>$

DATE: 2007-04-18

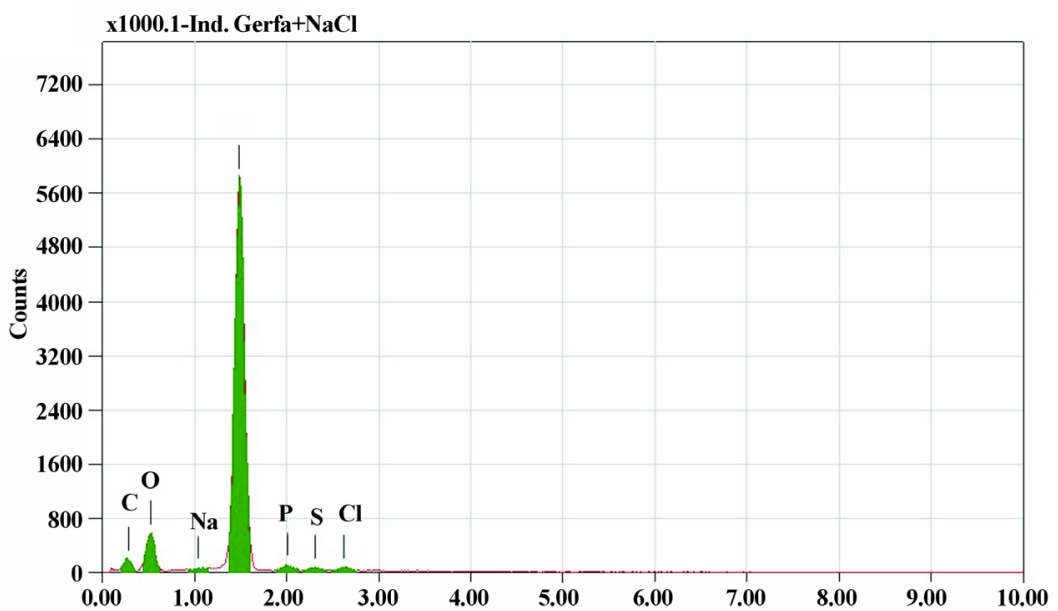

\begin{tabular}{|c|c|c|c|c|c|c|c|}
\hline Element & & $\begin{array}{c}\text { (ke V) } \\
0277\end{array}$ & mass\% $\%$ & $\begin{array}{l}\text { Error\% } \\
126\end{array}$ & Al\% & Compound & $\begin{array}{l}\text { Cation } \\
59186\end{array}$ \\
\hline $\begin{array}{ll}C & K \\
0 & K\end{array}$ & & $\begin{array}{l}0.277 \\
0.525\end{array}$ & $\begin{array}{l}29.40 \\
23.55\end{array}$ & $\begin{array}{l}1.26 \\
1.10\end{array}$ & $\begin{array}{l}43.33 \\
26.05\end{array}$ & & $\begin{array}{c}5.9186 \\
23.1325\end{array}$ \\
\hline $\mathrm{NaK}$ & * & 1.041 & 0.18 & 0.47 & 0.13 & & 0.2766 \\
\hline Al K & & 1.486 & 44.46 & 0.37 & 29.17 & & 67.1223 \\
\hline $\mathbf{P} \mathrm{K}$ & & 2.013 & 1.20 & 0.56 & 0.69 & & 1.6666 \\
\hline S K & * & 2.307 & 0.54 & 0.44 & 0.30 & & 0.8201 \\
\hline $\mathrm{Cl} \mathrm{K}$ & & 2.621 & 0.67 & 0.46 & 0.34 & & 1.0633 \\
\hline Total & & & 100.00 & & 100.00 & & \\
\hline
\end{tabular}

Figure 3. SEM and EDX of the In alloy after immersion in 5\% Cin $+\mathrm{NaCl}$ solution for 1 hour.
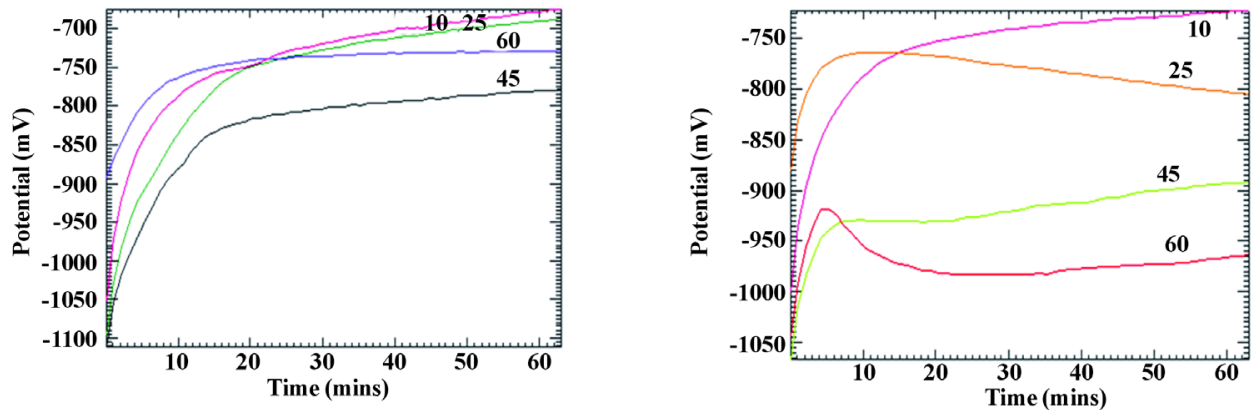

Figure 4. Effect of change of temperature on OCP of pure $\mathrm{Al}$ for 5\% Cin solutions (left) without $\mathrm{NaCl}$, and (right) with $\mathrm{NaCl}$. 


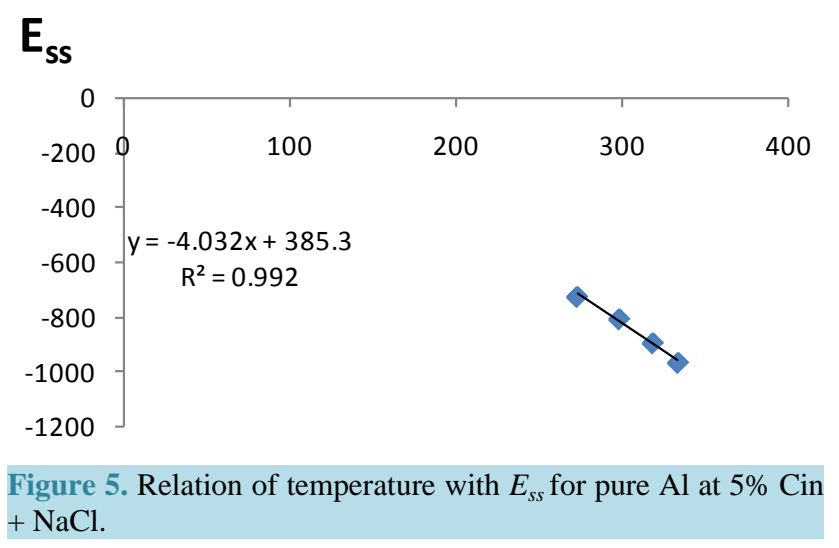

shown in Table 3. The values of $E_{s s}$ decreased after addition of chloride ions and decreased with increasing temperature. The electrochemical behavior of $\mathrm{Al}$ in presence of $\mathrm{NaCl}$ and the effect of temperature using the following equation was studied [22]:

$$
E_{s \mathrm{~s}}=a-b(T)
$$

When applying Equation (5) for pure $\mathrm{Al}$ at $5 \% \mathrm{Cin}+\mathrm{NaCl}$, it gave a linear relation for temperature $\left(\mathrm{R}^{2}=\right.$ 0.992) with a negative slope indicating thinning of the pre-immersion oxide film with increasing temperature as shown in Figure 5.

From the electrochemical methods, the Eg alloy showed an increase in the values of $E_{s s}$ at $60^{\circ} \mathrm{C}$ which indicated strengthening of the pre immersion Al oxide layer [25]. The change of the potential with time from OCP method reflected the effect of attack of the constituents of the solution. The resulting $E_{s s}$ is a mixed potential of all the anodic and cathodic reactions. It is known that $E_{s s}$ depends on $\mathrm{O}_{2}$ concentration, composition of $\mathrm{Al}, \mathrm{pH}$ and temperature [25]. The values of $E_{\mathrm{ss}}$ for $5 \%$ - 10\% Cin solutions were almost constant at $710-715 \mathrm{mV}$. For the In alloy it showed the same trend as the pure Al. On the contrary, the Eg alloy showed an increase in the values of $E_{s s}$ at $60^{\circ} \mathrm{C}$ which indicated strengthening of the pre immersion $\mathrm{Al}$ oxide layer [25]. The values of $E_{s s}$ decreased after addition of chloride ions and decreased with increasing temperature which indicated thinning of the pre-immersion oxide film. This phenomenon resembled the behaviour found for 8-hydroxy quinoline by Garrigues et al. [26]. The $\mathrm{pH}$ of the present study was $6.40 \pm 0.20$ in presence of $\mathrm{NaCl}$ solutions which is close to the neutral range. Mazhar et al., explained the competition between $\mathrm{OH}^{-}$and $\mathrm{Cl}^{-}$in neutral solutions which is explained in the following equation [27]:

$$
\left.\mathrm{Al}^{3+} \text { (in crystal lattice of the oxide }\right)+2 \mathrm{Cl}^{-}+\mathrm{OH}^{-} \rightleftharpoons(\mathrm{AlOH})_{2} \mathrm{Cl}_{2}^{-}
$$

The use of aerated solutions in the present study means that the cathodic reaction of oxygen reduction was applicable (Jones, 1995). Assuming that this was the cathodic reaction with the possible anodic reaction:

$$
\mathrm{Al}+3 \mathrm{Cl}^{-} \rightleftharpoons \mathrm{AlCl}_{3}+3 \mathrm{e}^{-}
$$

The resulting mixed potential is close to $E_{s s}$ obtained in the present study. The attack of $\mathrm{Al}_{2} \mathrm{O}_{3}$ may occur through voids and defected sites. A previous model by McCafferty considered that the penetration of $\mathrm{Cl}^{-}$ions can occur by film dissolution or by migration through the oxygen vacancies [21]. These defected sights are more prone to attack at high temperatures. Moreover using labeled chloride ions Kolice had shown that $\mathrm{Cl}^{-}$ions are incorporated to a distance of 10 - $15 \AA$ from the interphase of oxide/solution [20] chloride ions were adsorbed chemically on $\mathrm{Al}$ oxide film and reacted as partners in $\mathrm{Al}$ dissolution by forming oxy chloride ionic complexes.

\subsubsection{Tafel Plots Method}

Tafel method was performed to measure the current density $\left(I_{\text {corr }}\right)$ after OCP measurements reached $E_{s s}$. To study the effect of concentration, the temperature was kept constant at $60^{\circ} \mathrm{C}$. The results are depicted in Figure 6 . The following results were obtained as shown in Table 4:

1) For pure Al, the $I_{\text {corr }}$ values of Cin solution w/without $\mathrm{NaCl}$ are about $1.99 \mu \mathrm{A} / \mathrm{cm}^{2}$. The constant value of 

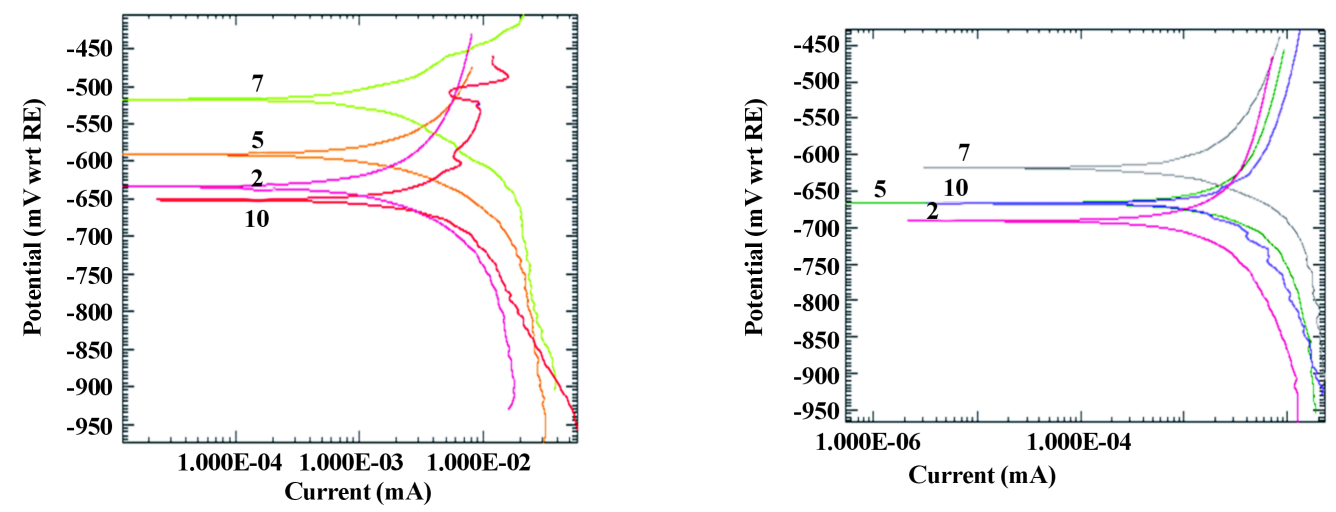

Figure 6. Tafel graphs of the two $\mathrm{Al}$ alloys (Eg left and In right) at $60^{\circ} \mathrm{C}$ with time at different Cin concentrations, $2=2 \%, 5=5 \%, 7=7 \%, 10=10 \%$.

Table 3. Effect of change of temperature on OCP of pure Al for $5 \%$ Cin solutions w/without $\mathrm{NaCl}$.

\begin{tabular}{ccccc}
\hline$T\left({ }^{\circ} \mathrm{C}\right)$ & 10 & 25 & 45 & 60 \\
$E_{\text {ss }}(\mathrm{mV}) \mathrm{Cin}$ & -674 & -687 & -779 & -728 \\
$E_{\text {ss }}(\mathrm{mV}) \mathrm{Cin}+\mathrm{NaCl}$ & -723 & -805 & -893 & -965 \\
\hline
\end{tabular}

Table 4. Electrochemical parameters of $\mathrm{Al}$ alloys for Cin solutions at different concentration from Tafel method.

\begin{tabular}{|c|c|c|c|c|c|}
\hline Alloy & $T\left({ }^{\circ} \mathrm{C}\right)$ & $\% \mathrm{C}(\mathrm{w} / \mathrm{v})$ & $\mathrm{B}_{\mathrm{a}}(\mathrm{mV} / \mathrm{dec})$ & $-\mathrm{B}_{\mathrm{c}}(\mathrm{mV} / \mathrm{dec})$ & $I_{\text {corr }}\left(\mu \mathrm{A} / \mathrm{cm}^{2}\right)$ \\
\hline \multirow{4}{*}{ Pure Al } & \multirow{4}{*}{60} & 2 & 106 & 73 & 1.99 \\
\hline & & 5 & 97 & 79 & 1.96 \\
\hline & & 7 & 97 & 79 & 1.93 \\
\hline & & 10 & 91 & 61 & 1.99 \\
\hline \multirow{4}{*}{ In $\mathrm{Al}$} & \multirow{4}{*}{60} & 2 & 86 & 75 & 0.75 \\
\hline & & 5 & 84 & 67 & 1.04 \\
\hline & & 7 & 97 & 107 & 1.25 \\
\hline & & 10 & 100 & 88 & 1.97 \\
\hline \multirow{4}{*}{$\mathrm{Eg} \mathrm{Al}$} & \multirow{4}{*}{60} & 2 & 93 & 85 & 0.73 \\
\hline & & 5 & 107 & 65 & 0.85 \\
\hline & & 7 & 83 & 88 & 1.08 \\
\hline & & 10 & 128 & 77 & 1.31 \\
\hline
\end{tabular}

$I_{\text {corr }}$ regardless of the increase in concentration indicates that the effective parameter in pure Al dissolution is the temperature.

For the Eg Alloy, the values of $I_{\text {corr }}$ are less than that of the In alloy. The values of $\mathrm{B}_{\mathrm{a}}$ increased slightly with increasing concentration while for $\mathrm{B}_{\mathrm{c}}$ values there were no regular trend. For the In alloy the values of $I_{\text {corr }}$ increased with increasing concentration. The trend was similar to the trend for $E_{s s}$. The values of $\mathrm{B}_{\mathrm{a}}$ increased but there were no obvious trend for values of $\mathrm{B}_{\mathrm{c}}$.

To study the effect of increasing the temperature on Tafel method, the electrochemical parameters were recorded for $1 \% \mathrm{NaCl}$ pure $\mathrm{Al}$ at $5 \%$ Cin solutions w/without $\mathrm{NaCl}$ at different temperatures as shown in Table 5. The following observations may be drawn:

- For $\mathrm{NaCl}$ solutions the $I_{\text {corr }}$ values were larger than their values for $\mathrm{Cin} \mathrm{w} /$ without $\mathrm{NaCl}$ at the same temperature. This result agrees with the aggressive role of $\mathrm{Cl}^{-}$ions in $\mathrm{Al}$ dissolution in neutral solutions. 
Table 5. Electrochemical parameters of pure $\mathrm{Al}$ for $5 \%$ Cin solutions w/without $\mathrm{NaCl}$ at different temperatures from Tafel method:

\begin{tabular}{ccccccc}
\hline Sol. & $\mathrm{T}\left({ }^{\circ} \mathrm{C}\right)$ & $\mathrm{B}_{\mathrm{a}}(\mathrm{mV} / \mathrm{dec})$ & $-\mathrm{B}_{\mathrm{c}}(\mathrm{mV} / \mathrm{dec})$ & $I_{\mathrm{corr}}\left(\mu \mathrm{A} / \mathrm{cm}^{2}\right)$ & $\% I E$ & $\mathrm{CR}(\mathrm{mm} / \mathrm{day})$ \\
\hline & 10 & 19 & 104 & 0.22 & -- & 0.933 \\
$\mathrm{NaCl}$ & 25 & 22 & 84 & 0.64 & -- & 2.71 \\
& 45 & 17 & 256 & 0.91 & -- & 3.86 \\
& 60 & 21 & 236 & 2.94 & -- & 12.47 \\
$5 \%$ & 10 & 79 & 72 & 0.13 & -- & 0.55 \\
$\mathrm{Cin}$ only & 25 & 75 & 62 & 0.23 & -- & 0.98 \\
& 45 & 77 & 85 & 0.39 & -- & 1.66 \\
& 60 & 97 & 79 & 1.02 & -- & 4.34 \\
$5 \%$ & 10 & 70 & 67 & 0.14 & 36 & 0.61 \\
$\mathrm{Cin}+\mathrm{NaCl}$ & 25 & 67 & 52 & 0.37 & 42 & 1.54 \\
& 45 & 67 & 67 & 0.40 & 56 & 1.68 \\
& 60 & 67 & 75 & 1.14 & 61 & 4.81 \\
\hline
\end{tabular}

- For 5\% Cin solution, the values of $I_{\text {corr }}$ increased with increasing temperature. There was a slight increase in $\mathrm{B}_{\mathrm{a}}$ values but there were no obvious trend for $\mathrm{B}_{\mathrm{c}}$.

- For $5 \% \mathrm{Cin}+\mathrm{NaCl}$, the values of $I_{\text {corr }}$ increased with increasing temperature. There were no obvious trend for the values of $\mathrm{B}_{\mathrm{a}}$ and $\mathrm{B}_{\mathrm{c}}$. The values of $I_{\text {corr }}$ of $\mathrm{Cin}+\mathrm{NaCl}$ were comparable to the values of $I_{\text {corr }}$ of $\mathrm{C}$ in solutions for each degree of temperatures. The $E I \%$ values range between $36 \%-61 \%$ which is in accordance with WL results.

To gain more insight about adsorption, the parameters of Tafel method were used to calculate some thermodynamic parameters for $1 \% \mathrm{NaCl}$ and $\mathrm{Cin} w /$ without $\mathrm{NaCl}$ using the following Arrhenius equation:

$$
k=A \mathrm{e}^{-E a / R T}
$$

Using Table 5, and applying Equation (8) to calculate $E_{a}$ of pure $\mathrm{Al}$ in Cin solutions w/without $\mathrm{NaCl}$ gave straight lines. The apparent activation energy values were calculated by plotting $\ln I_{\text {corr }}$ versus $1 / T$.

From the slopes of the graphs, the value of $E_{a}$ was calculated and the results are listed in Table 6.

Evaluating the thermodynamic parameters was done using the transition state equation,

$$
C_{R}=\frac{R T}{N h} \exp \left(\frac{\Delta S^{*}}{R}\right) \exp \left(-\frac{\Delta H^{*}}{R T}\right)
$$

where $h$ is Planck's constant, $N$ is Avogadro's number, $\Delta S$ is the entropy of the activation, and $\Delta H$ is the enthalpy of activation.

Drawing ln $C R / T$ vs. $1 / T$ gave a straight line with a slope of $-\Delta H_{\circ} / R$ and an intercept of (ln $\left.R / \mathrm{Nh}\right)+\Delta S_{\circ} / R$ ) as shown in Figure 7 for Cin w/without $\mathrm{NaCl}$ solution. The calculated parameters at $5 \%$ concentrations of the inhibitor are collected in Table 6.

From Tafel method, the values of apparent activation energy $\left(E_{a}\right), \Delta S$ and $\Delta H$ show the following trend:

$$
\mathrm{NaCl}>\mathrm{Cin}>\mathrm{Cin}+\mathrm{NaCl}
$$

The values of $E_{a}$ for Cin solution was $32.45 \mathrm{~kJ} / \mathrm{mol}$. The values for $E_{a}$ were 36.45 and $28.44 \mathrm{~kJ} / \mathrm{mol}$ for $\mathrm{NaCl}$ and $\mathrm{Cin}+\mathrm{NaCl}$ solutions respectively. The low value of $E_{a}$ of Cin solution w/without $\mathrm{NaCl}$ compared to $\mathrm{NaCl}$ indicates the ease of adsorption of Cin constituents on Al surface. The decrease in $E_{a}$ after adding Cin to $\mathrm{NaCl}$ may indicate a competition between Cin constituents to be adsorbed and Chloride ions to dissolve $\mathrm{Al}$ as $E_{a}$ of $\mathrm{Cin}+\mathrm{NaCl}$ is smaller than $E_{a}$ of Cin alone. This is in agreement with the trend of CR from WL results that Cin is a good inhibitor of $\mathrm{Al}$ dissolution in presence of $\mathrm{NaCl}$.

From Table 6, the trend for the thermodynamic values $(\Delta H, \Delta S)$ and $E_{a}$ is:

$$
\mathrm{NaCl}>\mathrm{Cin}>\mathrm{Cin}+\mathrm{NaCl}
$$


Table 6. Apparent $E_{a}$ and thermodynamic parameters of pure $\mathrm{Al}$ for Cin solutions w/without $\mathrm{NaCl}$.

\begin{tabular}{ccccc}
\hline Sol. & $\mathrm{pH}$ & $E_{a c}(\mathrm{~kJ} / \mathrm{mol})$ & $\Delta H(\mathrm{~kJ} / \mathrm{mol})$ & $\Delta S(\mathrm{~J} / \mathrm{K} . \mathrm{mol})$ \\
\hline $\mathrm{Cin}$ & $5.00 \pm 0.25$ & 32.52 & 28.03 & -151.1 \\
$\mathrm{NaCl}$ & $6.40 \pm 0.20$ & 36.55 & 34.00 & -124.5 \\
$\mathrm{Cin}+\mathrm{NaCl}$ & $6.40 \pm 0.20$ & 28.44 & 25.84 & -158.0 \\
\hline
\end{tabular}
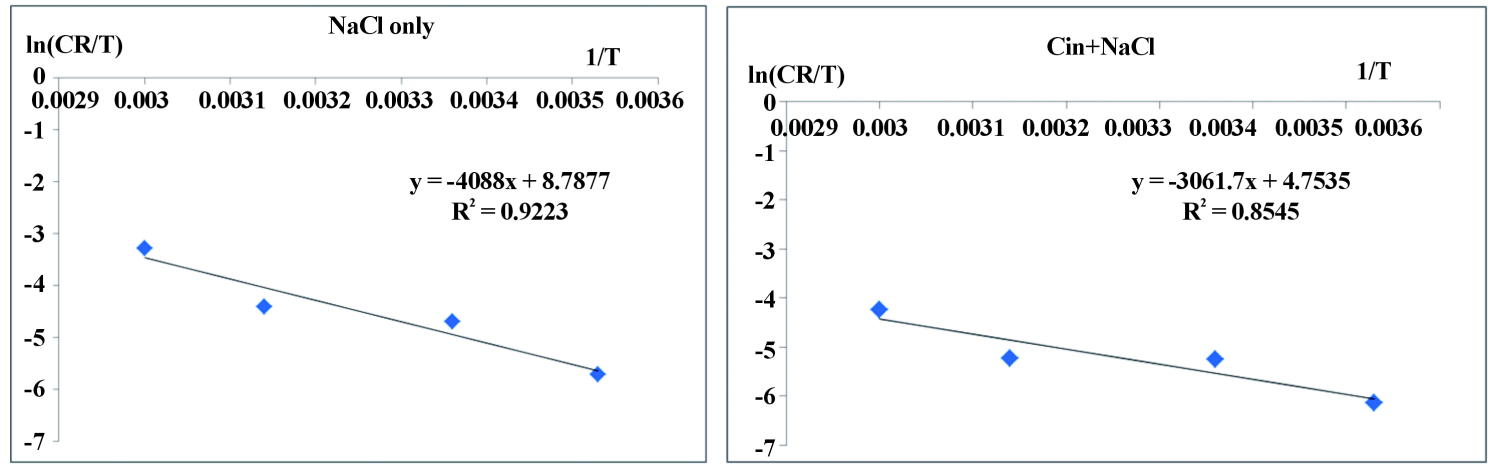

Figure 7. Applying transition state equation for $\mathrm{NaCl}$ with/without Cin solution at different temperatures.

The decrease in $E_{a}$ after adding Cin to $\mathrm{NaCl}$ may indicated a competition between Cin constituents to be adsorbed on $\mathrm{Al}$ surface as $E_{a}$ of $\mathrm{Cin}+\mathrm{NaCl}$ is smaller than $E_{a}$ of Cin alone. This is in agreement with the trend of CR from WL results that $\mathrm{Cin}$ is a good inhibitor of $\mathrm{Al}$ dissolution in presence of $\mathrm{NaCl}$. This result agrees with the trend of $E_{a}$ of Obot et al. in 2011 [17] and also with a previous study by Al Juhaiman et al. about Polyvinyl Pyrrolidone inhibition of carbon steel in neutral medium containing $\mathrm{NaCl}$ [28]. However, some researchers reported a large increase of $E_{a}$ for the blank + inhibitor compared to the blank although the CR of the metal decreased in presence of the inhibitor [11] [12] [15]. From the present study, the value of $E_{a}$ for Cin solution shown in Table 6 was $32.45 \mathrm{~kJ} / \mathrm{mol}$. The values for $E_{a}$ were 36.45 and $28.44 \mathrm{~kJ} / \mathrm{mol}$ for $\mathrm{NaCl}$ and $\mathrm{Cin}+\mathrm{NaCl}$ solutions respectively. The low value of $E_{a}$ of Cin solution w/without $\mathrm{NaCl}$ compared to $\mathrm{NaCl}$ indicated the ease of adsorption of Cin constituents on Al surface. It was surprising that the value of $E_{a}$ of $\mathrm{Cin}+\mathrm{NaCl}$ is less than the $E_{a}$ of Cin alone. It is a well-known fact that metal dissolution is $\mathrm{pH}$ dependent as shown from Pourbaix diagrams. Thus we think that the $\mathrm{pH}$ difference between the two solutions and Kolice et al. findings in 2001 may explain this ambiguity. The oxide film thickness on Al surface is strongly dependent upon the solution pH. Using XRF, Kolice et al. found "a slight thickness variation in the passive region of aluminum $(4<\mathrm{Ph}<10)$ which represented a film thickness of $40-45 \AA$ ” [20]. The pH of the present study was $6.40 \pm 0.20$ in presence of $\mathrm{NaCl}$ and $5.00 \pm 0.25$ in presence of Cin solution. From Table 2, Cin solution has inhibitive properties depicted in the lower $\mathrm{CR}$ compared to $\mathrm{Cin}+\mathrm{NaCl}$ and $\mathrm{NaCl}$ solutions. Thus we may postulate that due to the aggressive role of chloride ions, the thickness of the $\mathrm{Al}$ oxide film was less thicker for $\mathrm{Cin}+\mathrm{NaCl}$ compared to Cin solutions which needed a lower $E_{a}$ value as found in Table 6 .

The difference in $\Delta H$ and $\Delta S$ values between $\mathrm{Cin}$ and $\mathrm{Cin}+\mathrm{NaCl}$ solutions may be explained by the difference in $\mathrm{pH}$ using the same reasoning discussed for $E_{a}$ values. It is known that the positive sign of the enthalpies reflect the endothermic nature of the metal dissolution process. It is noticed that $\Delta H$ of Cin $+\mathrm{NaCl}$ solution is less than $\Delta H$ of $\mathrm{NaCl}$. That means that the adsorption process in presence of the inhibitor needs less energy compared to the blank which makes Al dissolution less favored and agrees with the results in WL and Tafel methods.

The elevated temperature had an adverse effect on adsorption process, as the intermolecular and intramolecular forces were weakened [10] [15]. For the change of entropy, Table 6 shows that $\Delta S$ of NaCl solution is larger than that of $\mathrm{Cin}$ w/without $\mathrm{NaCl}$ which means the increase in disorder in $\mathrm{NaCl}$ solutions than in presence of the inhibitor. The decrease in the value of $\Delta S$ for $\mathrm{Cin}$ w/without $\mathrm{NaCl}$ compared to $\mathrm{NaCl}$ only is logical as the inhibitor contains many constituents which may be bound to the Al surface by physical bonds as revealed from obeying the modified Langmuir adsorption isotherm which decrease the randomness in the system (increase the order). Although the present trend agree with some studies [17] [28] [29]; but the findings disagree with other 
studies as well [11] [12] [15] [30].

\section{Conclusions}

From WL result, the $\mathrm{Al}$ leaching of Cin solutions in DW and Tab W of both the In and Eg alloys at $90^{\circ} \mathrm{C}$ was less than the $\mathrm{Al}$ leaching without Cin solutions. The addition of Cin solutions in DW or Tab W to NaCl decreased the $\mathrm{Al}$ leaching in all concentrations for both $\mathrm{Al}$ alloys compared to $\mathrm{NaCl}$ solution alone. Comparing the $\mathrm{Al}$ dissolution in pure $\mathrm{NaCl}$ solution with $\mathrm{Cin}+\mathrm{NaCl}$ showed that Cin solution has inhibitive effect using both alloys but the $I E \%$ was higher in the Eg alloy. The results of Surface Study are in agreement with WL result.

From Tafel method it was found that current density at $60^{\circ} \mathrm{C}$ using $\mathrm{Al}$ alloys showed the following trend:

\section{Pure Al > In Al > Eg Al}

This indicates that some of the alloying elements in the Eg alloy played an inhibitive role in decreasing $\mathrm{Al}$ leaching. From Tafel method, the values of $E_{a}, \Delta \mathrm{S}$ and $\Delta \mathrm{H}$ show the following trend:

\section{$\mathrm{NaCl}>\mathrm{Cin}>\mathrm{Cin}+\mathrm{NaCl}$}

The solutions of $\mathrm{Cin}+\mathrm{NaCl}$ were less than those of $\mathrm{NaCl}$ only which are in agreement with WL results that $\mathrm{Cin}$ is a good inhibitor of $\mathrm{Al}$ dissolution. In conclusion using cinnamon in cooking may reduce the extent of $\mathrm{Al}$ leaching.

\section{Acknowledgements}

This research project was supported by a grant from the "Research Center of the Female Scientific and Medical Colleges”, Deanship of Scientific Research, King Saud University.

\section{References}

[1] Gitelman, H. (1989) Aluminum and Health. Marcel Dekker, Inc., NewYork.

[2] Neelam, Bamji, M.S. and Kaladhar, M. (2000) Risk of Increased Aluminum Burden in the Indian Population: Contribution from Aluminum Cookware. Food Chemistry, 70, 57-61. http://dx.doi.org/10.1016/S0308-8146(00)00068-6

[3] Soni, M.G., White, S.M., Flamm, W.G. and Burdock, G.A. (2001) Safety Evaluation of Dietary Aluminum. Regulatory Toxicology and Pharmacology, 33, 66-79. http://dx.doi.org/10.1006/rtph.2000.1441

[4] Tripathi, R.M., Mahapatra, S., Raghunath, R., Vinod Kumar, A. and Sadasivan, S. (2002) Daily Intake of Aluminium by Adult Population of Mumbai. Indian Science of the Total Environment, 299, 73-77. http://dx.doi.org/10.1016/S0048-9697(02)00224-3

[5] Ščančar, J., Stibilj, V. and Miačič, R. (2004) Determination of Aluminum in Slovenian Foodstuffs and Its Leachability from Aluminum Cookware. Food Chemistry, 85, 151-157. http://dx.doi.org/10.1016/j.foodchem.2003.07.028

[6] Verissimo, M.I.S., Oliveira, J. and Gomes, M. (2006) Leaching of Aluminum from Cooking Pans and Food Containers. Sensors and Actuators B, 118, 192-197. http://dx.doi.org/10.1016/j.snb.2006.04.061

[7] Fekete, V., Vandevijvere, S., Bolle, F. and Van Loco, J. (2013) Estimation of Dietary Aluminum Exposure of the Belgian Adult Population: Evaluation of Contribution of Food and Kitchenware. Food and Chemical Toxicology, 55, 602608. http://dx.doi.org/10.1016/j.fct.2013.01.059

[8] WHO/FAO (2007) Expert Committee on Safety Evaluation of Certain Food Additives and Contaminants. Food Additives Series, Geneva, 58, 119-207.

[9] Parthasarathy, V.A., Chempakam, B. and Zachariah, T.J. (2008) Chemistry of Spices. CABI International, London. http://dx.doi.org/10.1079/9781845934057.0000

[10] Noor, E.A. (2009) Potential of Aqueous Extract of Hibiscus Sabdariffa Leaves for Inhibiting the Corrosion of Aluminum in Alkaline Solutions. Journal of Applied Electrochemistry, 39, 1465-1475. http://dx.doi.org/10.1007/s10800-009-9826-1

[11] Obot, I.B. and Obi-Egbedi, N.O. (2009) Ipomoea Involcrata as an Ecofriendly Inhibitor for Aluminium in Alkaline Medium. Portugaliae Electrochimica Acta, 27, 517-524. http://dx.doi.org/10.4152/pea.200904517

[12] Chaieb, E., Bouyanzer, A., Hammouti, B. and Benkaddour, M. (2005) Inhibition of the Corrosion of Steel in 1 M HCl by Eugenol Derivatives. Applied Surface Science, 246, 199-206. http://dx.doi.org/10.1016/j.apsusc.2004.11.011

[13] Shalabi, K., Abdallah, Y.M., Hassan, R.M. and Fouda, A.S. (2014) Adsorption and Corrosion Inhibition of Atropa Belladonna Extract on Carbon Steel in $1 \mathrm{M} \mathrm{HCl}$ Solution. International Journal of Electrochemical Science, 9, 14681487.

[14] Hassan, R.M. and Zaafarany, I.A. (2013) Kinetics of Corrosion Inhibition of Aluminum in Acidic Media by Water- 
Soluble Natural Polymeric Pectates as Anionic Polyelectrolyte Inhibitors. Materials, 6, 2436-2451. http://dx.doi.org/10.3390/ma6062436

[15] Ibrahim, T.H. and Abou Zour, M. (2011) Corrosion Inhibition of Mild Steel Using Fig Leaves Extract in Hydrochloric Acid Solution M. International Journal of Electrochemical Science, 6, 6442-6455.

[16] Singh, A.K., Ebenso, E.E. and Quraishi, M.A. (2012) Adsorption Behaviour of Cefapirin on Mild Steel in Hydrochloric Acid Solution. International Journal of Electrochemical Science, 7, 2320-2333.

[17] Obot, I.B., Umoren, S.A. and Obi-Egbedi, N.O. (2012) Corrosion Inhibition and Adsorption Behavior for Aluminuim by Extract of Aningeria robusta in HCl Solution: Synergistic Effect of Iodide Ions. Journal of Material Environmental Science, 2, 60-71.

[18] Brillas, E., Cabot, P.L., Centellas, F., Carrido, J.A., Parez, E.R. and Rodfiques, M. (1998) Electrochemical Oxidation of High-Purity and Homogeneous Al-Mg Alloys with Low Mg Contents. Electrochimica Acta, 43, 799-812. http://dx.doi.org/10.1016/S0013-4686(97)00266-1

[19] Al Juhaiman, L.A., Al-Shihry, R.A. and Al-Hazimi, H.M. (2014) Effect of Cardamom Extract on Leaching of Aluminum Cookware. International Journal of Electrochemical Science, 9, 1055-1070.

[20] Kolice, A., Besing, A.S., Baradlai, P., Haasch, R. and Weickowski, A. (2001) Effect of Thickness and Ion Content of the Oxide Film on Al in NaCl Media. Journal of Electrochemical Society, 148, B251-B259. http://dx.doi.org/10.1149/1.1376118

[21] McCafferty, E. (2003) Sequence of Steps in the Pitting of Aluminum by Chloride Ions. Corrosion Science, 45, 14211438. http://dx.doi.org/10.1016/S0010-938X(02)00231-7

[22] Brett, C.M., Gomes I.A. and Martins, P. (1994) The Electrochemical Behavior and Corrosion of Aluminum in Chloride Media. Corrosion Science, 36, 915-923. http://dx.doi.org/10.1016/0010-938X(94)90194-5

[23] Da Browski, A. (2001) Adsorption from Theory to Practice. Advance Colloid Interface Science, 93, 135-224. http://dx.doi.org/10.1016/S0001-8686(00)00082-8

[24] Zucchi, F., Trabanelli, G. and Brunoro, G. (1994) Iron Corrosion Inhibition in Hot 4 M HCl Solution by t-Cinnamaldehyde and Its Structure-Related Compounds. Corrosion Science, 36, 1683-1690. http://dx.doi.org/10.1016/0010-938X(94)90123-6

[25] Jones, D.A. (1995) Principles and Prevention of Corrosion. 2nd Edition, Prentice Hall Engineering, New York.

[26] Garrigues, L., Pebere, N. and Dabost, F. (1996) An Investigation of the Corrosion Inhibition of Pure Aluminum in Neutral and Acidic Chloride Solutions. Electrochimica Acta, 41, 1209-1215. http://dx.doi.org/10.1016/0013-4686(95)00472-6

[27] Mazhar, M.A., Badawy, W.A. and AbouRomia, R.M. (1986) Impedance Studies of Corrosion Resistance of Aluminium in Chloride Media. Surface Coating Technology, 29, 335-345. http://dx.doi.org/10.1016/0257-8972(86)90006-X

[28] Al Juhaiman, L.A., Abu Mustafa, A. and Mekhamer, W.K. (2012) Polyvinyl Pyrrolidone as a Green Corrosion Inhibitor of Carbon Steel in Neutral Solutions Containing $\mathrm{NaCl}$ : Electrochemical and Thermodynamic Study. International Journal of Electrochemical Science, 7, 8578-8596.

[29] Obot, I.B., Obi-Egbedi, N.O., Umoren, S.A. and Ebenso, S.A. (2011) Adsorption Behavior and Kinetic Modeling of Fluconazole on Aluminium from HCl Solution. Chemical Engineering Communication, 198, 1-15. http://dx.doi.org/10.1080/00986445.2011.532746

[30] Ameer, M.A. and Fekry, A.F. (2011) Inhibition Effect of Newly Synthesized Heterocyclic Organic Molecules on Corrosion of Steel in Alkaline Medium Containing Chloride. International Journal of Hydrogen Energy, 35, 11378-11396. 